\title{
Eating people and the alimentary logic of Richard Cour de Lion
}

\author{
Nicola McDonald
}

\section{$I$}

Test de Turt. Foille de pastee bon sarrays, \& iplaunted prin conynges \& volatils, dates ywaschen \& isouced in hony, chese neowe icoruen pryn; clouwes, quibebes, sucre abouen. Soppen on legge of fassyng of festigade gret plentee, pe colour of pe farsure red, zolou \& grene. Pat hed schal beon blake adressed ope manere of hier of wymmon on an blake dische, \& a monnes visage abouen. Dinersa Cibaria (c. I 300$).{ }^{\mathrm{I}}$

[Turk's Head. Take a well-rolled sheet of pastry; fill it with rabbit, fowl and honey-soaked dates; add fresh cheese and put cloves, cubebs and sugar on top. Then lay on a face with plenty of ground pistachio; the filling will be coloured red, yellow and green. Dress the head in black, in the manner of a woman's hair, and place it on a black dish. A man's face should be visible on the top.]

'Eating people is wrong." Western culture has always treated the eating of human flesh as taboo. Reluctant or not, cannibals evoke fear, loathing or, at best, horrified pity; by disturbing the neat, almost sacred, divide between edible and inedible, they challenge the very integrity of what it is to be human. And that taboo is, apparently, timeless: just as today deeply ingrained codes of gustatory behaviour prevent us serving dead relatives or despised neighbours for dinner, so too in the Middle Ages it was neither proper nor permissible to feast on the flesh of another human being. That said, cannibalism is not simply 'wrong'; cannibals more appropriately anthropophagi, since the former term signals little more than Columbus' wilful slander of the Carib natives ${ }^{3}$ - inhabit a world of nightmare, but it is a nightmare in which cultural prohibitions 
are played out against fantasies of race, sex and imperialism. We don't eat people, they do: medieval mappaemundi, like John Mandeville, conveniently locate the man-eater on the margins of the known world; responsibility for the gruesome tales of anthropophagy that, inevitably, surface nearer home is levelled at those already beyond the pale, Jews and other outcasts. ${ }^{4}$ Yet for all of its determination to purge itself of blame, and squeamishness aside, Western culture (medieval and modern) is no stranger to the notion that eating people is also a palatable pastime.

No fourteenth-century English cook is known to have prepared for consumption the flesh of a real Turk, yet the Turk's Head, a sweetand-sour meat pie shaped and decorated to resemble the outlandish features of a stereotyped Saracen, was a familiar late medieval dish. Instructions for how to prepare test de turt, all carefully delineating the colours and features of the upturned face, survive in no fewer than three manuscripts, two English and one, the earliest, in AngloNorman. Most medieval cookery books are assumed to serve the noble household - the cost and diversity of the ingredients (in particular meats and spices) and the quantities invoked require a large, wellfunded kitchen - but Diuersa Cibaria, the collection which includes the Turk's Head, found a broader, albeit still exclusive, audience: the earliest English manuscript belonged to Friar William Herebert of Hereford and the recipes' explicit is written in his hand. Neither Herebert nor any of the other fourteenth-century English householders who served up the Turk's Head were, I am confident, practising anthropophagi. The dish is designed not to remind them of 'Turks I have eaten' but to bring a touch of exotic levity to the table. Like the cokantrice (a fantastical beast composed of the forefront of a chicken and the hind quarters of a suckling pig) or the popular plate of mock raw meat ('how somme mete schalle seme raw'), the Turk's Head is evidence of the medieval penchant for illusion, or counterfeit, food: dishes that surprise or entertain by the way in which they counter, either in composition or appearance, culinary and/or gustatory expectations. ${ }^{5}$ The Turk's Head shares with other early fourteenth-century entremets (the generic term for a small dish served between the primary courses or mets) a fundamental edibleness. These are not the flamboyant spectacles of fifteenth-century court feasts that, constructed from cardboard, spun sugar and other inedibles, are intended not for consumption but solely for shock and astonishment. ${ }^{6}$ It is the very edibleness of the Turk's Head - the lip-smacking relish with which the diner bites into the aromatic flesh, the grinding of teeth and satisfied swallow, the appetite for more - that makes it more than just a neat 
piece of propaganda (like the battle between Saracens and Christians staged at Charles V's Twelfth Night dinner in I378). ${ }^{7}$ It is a licence, metaphorically at least, to eat people.

According to structuralist anthropologists, food must be not only 'good to eat' but 'good to think'. ${ }^{8}$ Cuisine, the transformation of raw into cooked, is a language that encodes both the essential ordering (the structure) of a society and its hidden contradictions. Key to any understanding of the Turk's Head as a cultural sign is, surely, a recognition of its inherent contradiction, or destabilisation, of the neatly ordered binaries that, so the structuralists tell us, produce and regulate meaning: edible/inedible, literal/metaphoric. It is only when we confront the inadequacy of binary opposition - when we unpick the comfortable, easy categories that make us confident that medieval (and modern) diners don't eat people - that we can begin to understand what is at stake in the early fourteenth-century recipe for test de turt. On the one hand, eating the Turk's Head mirrors crusader fantasy: Christians consume Saracens in their conquest, real or desired, of the Holy Land. On the other hand, by literalising the rhetoric of conquest, it makes the unimaginable transgression (eating Saracens) completely imaginable. Like sex and commerce, medieval politics, in particular the politics of national expansion, is fraught with the anthropophagic urge: lords 'ethep' their underlings and 'deuouren' the poor; knights 'swolwe' one another and so too do kingdoms; enemies are 'glotons'; and victors 'feste' on hard-won land. ' Structured as opposites, edible and inedible, literal and metaphoric are rather points on a continuum. The Christian fantasy of Muslim genocide - the total decimation of land and people imagined in a Middle English romance as an act of ingestion ('pou ... destroyyst hys [the Sultan's] countrays, / Slees hys men, and eetes among' $)^{10}-$ is, if we are being honest, pretty much coincident with the diner's ingestion of a pie not only imagined as, but made out to look like, a Turk. Both invoke eating people as a trope to make real (imaginatively and materially) a fantasy of total power. Once that power has been acknowledged, then the next step - only a small shift along the continuum - becomes possible: the material Turk (human flesh and blood) is imagined - and prepared/cuisiné - as a dish and his ingestion stands in for, and confirms, the fantasy of power.

I remarked above that Western culture has, if not embraced, then at least normalised some forms of eating people. The medieval Turk's Head is one example of how anthropophagy functions alongside, or, more precisely, within, conventional methods of nourishment, but it is not unique. Indeed, it is the very ordinariness of the anthropophagic 
gesture and its longevity that interests me. The most rarefied instance of culturally validated anthropophagy is, of course, the theophagy at the heart of Christian ritual: Catholic doctrine, confirmed in I2 I 5 at the Fourth Lateran Council, teaches that the eucharist is truly the flesh and blood of Christ (corpus verum) ${ }^{\mathrm{II}}$ I will look more closely at theophagy in section III of this essay, but for the moment, the less exalted evidence is more relevant. The medieval Turk's Head has no identifiable progeny (the meat-pie version disappears after the Middle Ages), yet the trope is remarkably resilient. Jellies depicting the Turk's distinctive turban - called alternately Turk's Heads or Turk's Caps - are popular in England in the eighteenth century (and the moulds remain in catalogues of household ceramics into the twentieth); they are said to commemorate the Christian victory over the Ottoman Turks at the Siege of Vienna in I683. The Turk's Head surfaces in American kitchens at the start of the nineteenth century, this time as a cake whose form resembles the turban-like, central European kugelhupf (itself associated with the gustatory aftermath of I683); bakeware giants, like Hillside Metal Ware, still manufacture a ring-shaped, aluminium 'Turk Head' mould. ${ }^{12}$ And the trope is by no means limited to AngloAmerican cuisine; sweet domed pastries, topped with chocolate and called variously Schwartzkopf, Möhrenkopf and tête de nègre are standard items in European patisseries. The easy shift between Turk, Moor and Black, like that between turban and the anthropomorphic head, is instructive. The Turk's Head no longer serves an active commemorative function (few will identify the allusion to the Crusades or the Siege of Vienna), but it is no less key to an understanding of the complex racial and religious bigotry that underlies dominant Western ideology. Stigmatised as an object of both fear and fascination, the Muslim, reduced to a symbolic turban or a grinning face, ${ }^{\mathrm{I3}}$ can be eaten. His supremacy in the medieval Holy Land, his incursion into the heart of Renaissance Europe, his threat to American hegemony is contained, imaginatively at least, when, transformed into something edible, he is ingested. In the endless reiteration of animosity, Israeli prime minister Ariel Sharon, in a candid moment during the $200 \mathrm{I}$ election campaign, provides a salutary reminder that the line between the literal and the metaphoric is almost imperceptible: 'I am known as someone who eats Arabs for breakfast. ${ }^{14}$ Eating people then has very little to do with conventional morality, as 'wrong' implies; it is rather part - a legitimated one at that - of the complex way in which we, as individuals and communities, determine who we are. It has everything to do with who's cooking. 


\section{28 Nicola McDonald}

Richard Cour de Lion, a romance whose medieval popularity is well attested, arrests modern readers with the spectacle of its man-eating king. Duped into mistaking a cooked Saracen for pork, the ailing Richard devours a dish of boiled flesh, faster than his steward can carve, and gnaws on the bones. Once revived, he demands a second meal and, when confronted with a detached and grinning black head, he laughs. Richard then invites a party of Saracen ambassadors to dinner and serves the cooked heads of his aristocratic Muslim captives as a first course; each head is placed face-up on a platter; its lips are splayed and on its forehead is pinned a parchment tag displaying the victim's name. Richard again eats voraciously, pausing only to register his guests' horror. He finally orders them home armed with the gruesome message that he will not leave the Holy Land until all the Saracens are eaten up. 'Nonsense' decrees George Ellis, Richard's first modern editor; 'absurd' concurs Sir Walter Scott. What rankles the early commentators - and what still impedes our appreciation of the poem - is the conviction that these 'monstrous' incidents, so blatantly fabulous, 'disfigure' or (as Finlayson puts it) 'contaminate' the historical record of Richard's chivalric career. 'True history', Finlayson asserts, is 'at the base of this work'; fictitious accretion has turned the 'rigorously heroic' into a mere romance, 'impenetrable' (as Barron insists) 'to the discriminations of historians'. ${ }^{15}$ Richard's reputation as a composite romance, mingling fact and fiction, leaves scholars, almost without exception, picking over its plot in pursuit of anything authentic or factual. Not surprisingly, it is found wanting.

Richard's anthropophagy is historically unproven and, despite Arab suspicions that he did eat his victims, it is doubtless unverifiable; but it is certainly not absurd. ${ }^{16}$ As Geraldine Heng has recently demonstrated, Richard's consumption of the Saracen - in particular the racially marked head (the 'swarte vys' and 'blacke berd', the 'whyte teep' and 'lyppys ... wyde' (32 I I-I3)) - symbolically corroborates his crusader ideology: 'aggressive territorial ambitions, the consumption and discipline of alien communities' ${ }^{17}$ Richard's 'black humor' putting interpretive weight on Richard's extravagant laughter, Heng insists it is constructed as a joke - is not romance 'nonsense', but a function of the 'color politics' of both the poem and the Third Crusade. And Heng is more emphatic still: this joke is the interpretive key to Richard's political logic. Like Heng, I want to insist on the logical centrality of Richard's repeated anthropophagy, but my interest is 
only tangentially political. What I will argue is that eating people is essential to, and underscored by, the text's narrative logic, that the poetic mechanism that initiates and sustains Richard, not only makes sense of, but demands his anthropophagy. The logic that governs Richard is alimentary.

To be fair, the ongoing critical interest in the historicity of Richard Coeur de Lion is in part a product of its extant manuscripts. ${ }^{\text {I8 }}$ The earliest version of the poem - identified by both Gaston Paris and Karl Brunner as a translation of a now lost Anglo-Norman original ${ }^{19}-$ is found in the Auchinleck manuscript (c. I330); it charts the key military events of the Third Crusade (II89-92) with virulent nationalism. English identity is constructed not simply in opposition to the racially marked infidel, but also against the treachery of the French and their king, Philip Augustus. In response to a papal call-to-arms, Richard sets out for Jerusalem. He meets Philip in Messina and winters there; skirmishes between the Messinesi and English troops compel Richard to assault and take the city. He sets out again in late spring only to come ashore at Cyprus where some of his fleet have, a few weeks earlier, been wrecked and pillaged, their sailors murdered or imprisoned. Richard challenges the Cypriot emperor, defeats him, and takes control of Cyprus. He sets out again, intercepts and defeats a Saracen supply ship, and finally arrives at Acre. Richard learns of the deprivation suffered by the crusader armies camped at Acre and begins his attack on the Saracen city. At this point the fragmentary Auchinleck text breaks off, but it is not hard to guess what originally followed: Richard's victory at Acre and his slaughter of the Saracen prisoners; Philip's return to France; the decisive victory at Arsuf; the occupation of Jaffa; the removal to, and refortification of, Ascalon; the battle of Darum; the defence of Jaffa; and finally the three-year truce with Saladin guaranteeing free passage to Jerusalem for Christian pilgrims. In all likelihood, the original poem concluded with a short account of Richard's journey home and his death. ${ }^{20}$

This broad military narrative (from the crusade's inception to the truce, concluding with Richard's death) underlies all extant copies, in manuscript and print, of the Middle English romance. While Brunner divides the extant texts into two distinct groups - a shorter, more historical narrative and a longer version interpolated with fabulous romance material - the evidence is more complicated. No text of Richard, other than that found in Auchinleck, is wholly devoid of socalled romance material and it is impossible to tell - even if we believe the Paris/Brunner chronology (Anglo-Norman source, Middle English 
translation, Middle English elaboration) - whether the romance elaboration is the product of one or more redactors. ${ }^{21}$ While most scholars are interested in going backwards to trace the shape of either the (hypothetical) Anglo-Norman source or the earliest Middle English version, I want to move in the opposite direction to look at how the romance narrative works and to examine how Richard's anthropophagy plays a logical, and fully integrated, role in that narrative. The text of Richard printed by Brunner (Cambridge, Gonville and Caius, MS I75/96 supplemented by the two Wynkyn de Worde prints) represents the fullest, the most 'contaminated' and most romance-like, version of the poem. It offers us the opportunity to explore the mechanics of romance logic, to think about how the internal narrative coherence that is crucial to romance is actually achieved.

The transformation of Auchinleck's 'history' of the Third Crusade into a full-blown 'romance' is primarily effected by the interpolation of a series of episodes, many of which draw on stock romance motifs. The crusade is prefaced by a I200-line account of Richard's birth (to Henry II and a faerie queen Cassiodorien who, when compelled to remain in church for the duration of the mass, flies through the roof never to return), his secret sponsorship of a pre-crusade tournament (at which he fights three times in, alternately, black, red and white disguise) and a preparatory pilgrimage to the Holy Land with his righthand men (Thomas Moulton and Fulk D'Oilly, two Lincolnshire knights - not otherwise known as famous crusaders - whose families may have patronised Richard's poet). On his return from pilgrimage, Richard is imprisoned by the King of Almeyne and the King's son challenges him to an exchange of blows. Richard wins, killing the son and prompting the Duke to offer him up to the mercy of a starved lion. The King's daughter Margery falls in love with Richard and offers to help him. Richard rips out the lion's heart, gains his familiar sobriquet, and returns to England to launch his crusade. The narrative of the crusade itself is also expanded, but since Auchinleck is imperfect it is impossible to tell exactly how much is the product of later interpolation. In addition to a series of new (predominantly fictional) battles designed to exemplify the martial valour of Moulton and D'Oilly, the key 'meruayle[s]' (2683) include the following: Richard's first attack on the Saracens at Acre (he erects a multi-coloured, flaming mill that noisily emits a blood-like substance, terrifying the onlookers who assume it grinds Richard's victims); his unwitting consumption of Saracen flesh during the siege of Acre; his anthropophagic feast for the Saracen ambassadors after securing Acre; and his combat - astride a 
devil-possessed horse (a treacherous gift from the Saracens) - with Saladin. ${ }^{22}$

As I have just described it, Richard's anthropophagy comprises two discrete compositional units slotted into a pre-existing narrative. It is the blatant mechanics of this kind of plot construction that repeatedly draws critical contempt for romance and its audiences. What I want to demonstrate, however, is the extent to which these anthropophagic interpolations not only function in dialogue with other (interpolated) 'romance' episodes, but participate fully in the discursive, or poetic, logic that makes this text cohere. I remarked above that the logic that governs and sustains Richard is alimentary. By this I mean that the narrative, put crudely, is animated by Richard's hunger. As Fielding says of Homer's Odyssey, Richard is a great 'eating poem'. ${ }^{23}$ Eating - from the culinary practicalities of food preparation to the symbolic resonance of the anthropophagic banquet - is here informed by two imperatives: feast and fast. Like other binaries, they are simultaneously opposite and contiguous. Feasting has long been recognised as a key feature of Middle English romance. Romance feasts, like their historic counterparts, are overdetermined sites of social (as well as political and economic) contestation: with their complex hierarchies of seating and food consumption (only those at the high table, for instance, enjoy the most expensive and elaborate dishes) they confirm social division while at the same time uniting all of the diners, at least for the duration of the meal, in a utopic experience of commensality. And implicit in the exhibitionist hospitality that characterises so many medieval feasts is the spectre of alimentary deprivation: alongside the liturgical cycle of fast and feast is the very real hunger that is the inevitable corollary of both widespread famine and a seasonal food economy. ${ }^{24}$

No matter where we look in Richard we are likely to find food or, in its absence, hunger. The text is jammed with alimentary detail. Fluctuating food prices, methods of cooking, inventories of fish, fowl, meat and other edibles, the provision of tableware, and the slurps of hungry eaters repeatedly remind us of the vitality of food and its consumption. The poet knows that taste is a cultural construct, that it divides nations and races, and that it is subject to the vagaries of fashion; he knows the nutritive value of a balanced diet and the dangers of insufficient or spoiled food; and he knows too that food is a tool to seal friendship and confirm animosity. As is often the case in romance, the poetic formulae - the stock, reiterated phrases and motifs that are commonly dismissed as meaningless - provide a useful guide 


\section{I32 Nicola McDonald}

to the text's preoccupations and assumptions. More than twenty meals are recorded in Richard - over half of them formal feasts - but rarely do they merit more than a few lines: the board is set, the trumpets blown, and we are simply told 'pey eeten and drank and maden ham glade' (I I3). As the poet makes clear: 'knyztes seruyd pere good spede, / Off what to telle it is no nede' (I 57-8). Feasts mark key narrative incidents (like Cassiodorien's arrival at London, the start of Richard's crusade, and the victory in Cyprus), while more informal meals signal social cohesion (Richard's reconciliation with the King of Almeyne), erotic intrigue (Richard's liaison with Margery) and general well-being (Richard's shipmates celebrate their arrival at Acre with a round of drinks). Conversely, a meal interrupted (like the roast goose that is left unfinished when Richard and his companions are captured in Almeyne) inevitably presages a breakdown in order and hierarchy. In Richard, meals function as a form of narrative punctuation (they conclude or initiate action) and the poet expects his audience to understand their significance with only minimal textual prompting. What gives resonance to all of Richard's eating is the threat of hunger.

Hunger kills: this is the inescapable reality of the crusaders' wars. On two separate occasions, Richard is directly confronted with the spectre of enforced starvation. At the start of his crusade, he travels to Almeyne to settle accounts with the king, Modard. When he arrives at Cologne, he is unable to buy fowl, the poet's shorthand for meat, and learns that all sales to the crusaders have been prohibited ("pe hye mayere off pat cyte / Comaundyd ... / No man selle hem no ffowayle' (I477-9)). Modard is identified as responsible and his motivation is clear: 'he wenes, sykyrly, / pat ze schal haue mete non; / pus he pynkes zoure men to slon' (I490-2). Richard's reaction to Modard's alimentary warfare is instructive; threatened with hunger, he commands his men to make do with whatever is available: fruit and nuts as well as wax, tallow and grease. This mixture of low status food and the conventionally inedible provides a model for survival that is reiterated when Richard reaches Acre. The archbishop of Pisa details the hardship suffered by the Christian troops camped outside the city. At the onset of winter, with their supply lines cut and local prices outrageously inflated, the men are forced to slaughter and eat their horses; the traditionally taboo flesh is rationed and everything is consumed: guts, head and blood $(2837-76){ }^{25}$ The poet insists on the necessity of the crusaders' alimentary solution - 'pey myzte haue non opir pyng' (2875) - and, in his reiteration of hunger's dire consequences ('ffor hungyr oure ffolk it slowz; / ffor hungyr we loste', 'oure folk vnwexe, / 
and dyede for hungyr and ffor woo' $(2842-3,2864-5)$ ), he confirms the merit of a pragmatic diet. But the spectre of hunger is more pervasive still. The provision of food supplies, essential to a wellmanaged military campaign, is the kind of functional detail that is often elided in romance narrative, yet in Richard it is part of the formulaic fabric of the text. ${ }^{26}$ Key supplies, like meat, bread or simply vitayle, are as much a part of the poet's martial vocabulary as armour (and other military effects) and treasure or booty; indeed, as the formulaic homology makes clear, food is both military effect and treasure. Richard's ships leave England 'wel vitailid, / wip flour, hawberkes, swerdys, and knyuys' (I390-I); they are 'chargyd' the poet reiterates 'wip armure, drynk, and mete' (I662); when the crusaders raid a Saracen camp they win 'whete, bred, and wynes, / gold, and syluyr, and bawdekynes' (2797-8); similarly the victory at Acre explicitly promises 'ryche tresore': 'helmes and hawberkes ... / And oper ryhchesse ... / Whete jnow3 and opir tresore' (33 IO-I3); and these are not isolated examples. What strikes Richard's reader is the way in which food saturates every level of the narrative, informing and giving dimension to a whole range of (apparently trivial) textual detail.

I want now to return to the question of Richard's anthropophagy and its logic. The two occasions on which Richard explicitly consumes human flesh are not, as commentators often imply, isolated or aberrant incidents of dietary transgression. They are embedded in a narrative that is acutely aware of the practical and symbolic function of food and whose alimentary code, oscillating between the competing demands of fast and feast, is resolutely pragmatic. Modern readers are affronted by the narrative's endorsement of Richard's barbarity: some ascribe it to the imagined temper of the times, blood-thirsty and cruel; for others it simply defies comprehension. Yet neither of these explanations is very satisfactory. In section I of this essay I argued that eating people (contrary to basic assumptions) is not in fact uniformly taboo, that the anthropophagic act can be - and is - a standard, even legitimate, feature of medieval and modern cuisine. I want to propose that Richard's anthropophagy is likewise licensed. Although Richard's consumption of the Saracen is shocking (for fellow crusaders and the romance audience), it neither elicits narrative censure nor, I would argue, the opprobrium of its original audience. The fact that both Saracen and French (the anti-types against whom the English Christian is measured) do censure Richard (explicitly and implicitly, respectively) only serves to confirm the narrative's endorsement of his diet. ${ }^{27}$ The romance narrative embraces the taboo inherent in anthropophagy 


\section{I34 Nicola McDonald}

while, at the same time, insisting that eating people makes culinary and cultural sense. What I will explore below is precisely how this 'sense' is achieved.

If, for a moment, we ignore the cultural taboos that prohibit anthropophagy, eating people is an inspired resolution of the crusaders' military ambitions and their alimentary needs. Anthropophagic annihilation (the total consumption of a people) not only mirrors the crusaders' political and religious aspirations, as Heng argues, but fuels those aspirations (it provides the crusaders with the alimentary sustenance that is otherwise in short supply), and - if successful - guarantees the impunity of Christian hegemony. All eaten up, the threat of the infidel is eradicated. Richard's strategy of anthropophagic annihilation is horrifically brilliant. And it is this brilliance that the romance endorses: Ioo per cent. Richard is foiled only because he has to return to England to quell his brother's attempted usurpation of the throne; neither the narrator nor Richard's fellow crusaders ever doubt the efficacy or appropriateness of the anthropophagic solution. Eating people makes an awful lot of pragmatic sense.

Yet, Richard does not simply demand that we ignore the taboos. Instead, it purposefully makes eating people an identifiable and legitimate feature of the culinary system that prevails not only in this romance but in late medieval Europe. The insertion of 'Saracen' into a known culinary world, subject to the alimentary codes that structure everyday dining, renders what is otherwise alien and forbidden a familiar, and thus edible, food; it effectively diffuses the taboo that makes man-eating, if not unthinkable, unpalatable. Significantly, in order to effect its legitimation of eating people, Richard exploits the anthropophagic potential already present in medieval cuisine.

The incorporation of human flesh (the meat itself) into the familiar medieval culinary system is first, and not surprisingly, achieved by means of the cooking process. The initial proposal to eat human meat (offered in response to the ailing king's insatiable hunger for pork) immediately establishes the pattern of what I will call culinary accommodation: 'Takes a Sarezyn 3onge and ffat', demands one of Richard's trusted companions,

Jn haste [see] pat pe peff be slayn,

Openyd, and hys hyde off fflayn,

And soden fful hastyly,

Wip powdyr, and wip spysory,

And wip saffron off good colour. (3088-93) 
The old knight's command, right from the opening (and near obligatory) 'take', precisely mimics not only the lexis and syntax of conventional medieval recipes, but their imperative mood and abbreviated style. Only the designation 'peff' and the twice-repeated request for 'haste' signals that 'Sarezyn', a term current in medieval cookery books to denote exotic foods of Eastern origin, is not a standard English dish. ${ }^{28}$ The transformation of a young Muslim into a plate of pork (the meat that is the ubiquitous mark of a Christian diet) is achieved by subjecting the unfamiliar flesh to the normal rules of English cooking. Boiled, flavoured with spices and coloured a popular saffron yellow, Richard's fresh portion of Saracen neither looks nor tastes any different from the meat to which he and the crusaders have been culturally accustomed. This is in marked contrast to conventional depictions of the man-eater in romance and elsewhere that preserve the physical integrity (and sometimes even the vitality) of the human meat in order to insist on the transgression that its consumption necessarily entails. The giant of Mont St Michel recorded in Geoffrey of Monmouth's life of King Arthur, for instance, eats vanquished knights half alive (seminiuos) and, in the Alliterative Morte Arthure, he barbecues infants whole. ${ }^{29}$ Likewise in Matthew Paris' illustrated Chronica Universale (Cambridge, Corpus Christi College, MS I6), the Tartar's feast is a riot of severed heads and disassembled limbs; one Tartar bites into a blooddrenched leg (its pair held in eager anticipation) while a second turns a full-length skewered boy over the hot embers of a roasting pit. ${ }^{30}$

When Richard articulates his anthropophagic solution - eating up the enemy - to the English crusaders, he carefully links pragmatism ('Schole we neuere dye for defawte, / Whyl we may ... / Slee Sarezynys' (32I9-2I)) with gustatory satisfaction: does Saracen really taste this good? ('is Sarezynys flesch pus good?' (32 I6)). He reiterates the recipe formula - 'take' 'pe flesch' (322I) - and proposes a complete programme of culinary accommodation: 'Sepen, and roste hem, and doo hem bake' (3222). Boil, roast, and bake: all of the ordinary things English people do to their meat. By the time the English sit down to dinner with Saladin's messengers, 'Sarezyn' is accorded the status of a national dish; its privileged position in the formulaic list of meat that's good to eat (the kind of list we always find in descriptions of feasts, real and imagined $)^{31}$ is intended, not I think to single it out as an alimentary abomination, but to confirm its legitimate place in the English diet:

Per is no fflesch so norysschaunt

Vnto an Ynglyssche Cristen-man, 
Partryck, plouer, heroun, ne swan,

Cow ne oxe, scheep ne swyn,

As is pe flesshe of a Sarezyn. (3548-52)

The alignment of Saracen (as something edible) with the established linguistic and culinary codes of English cuisine is a consistent feature of the way the romance depicts Richard's (and by extension English) anthropophagy. Yet, I don't finally want to give the impression that this process of accommodation wholly neutralises anthropophagy. Culinary acculturation renders eating people acceptable (it no longer provokes the horror or disgust associated with the consumption of a taboo food), but it does not make it any less effective as a tool for social and political negotiation.

The spectacle of severed Saracens' heads, stripped of hair, cooked, and laid out, face up and grinning, on serving platters is certainly designed to shock Richard's dinner companions (both Saracen guests and crusaders) and, with them, the romance audience. Richard's subsequent and hearty consumption of a steaming head must elicit a gasp of disbelief and it is no doubt disturbing. The anthropophagic banquet, detailed at length and recounted twice (once by the narrator and a second time, immediately afterwards, by a messenger on his return to Saladin), does not seem, to the modern reader, to fit the process of culinary acculturation, and with it accommodation, that I have documented so far. The head, furnished with an identifying and personalising name tag, remains resolutely human; its upturned, grinning face openly flouts the taboos that conventionally prohibit anthropophagy. I began this essay with a fourteenth-century recipe for Turk's Head, a meat pie shaped to resemble a Turk's (or Saracen's) face that functions as a kind of comestible entertainment. As far as medieval party tricks go, the Turk's Head is pretty tame. A grotesque caricature of someone few English diners will have ever seen, its consumption confirms inherited racial and religious prejudice; there is nothing inherently difficult about its preparation and the required ingredients are all readily available. Yet, ultimately its success as a dinnertime diversion depends on the way that it, much like the real Saracens' heads served at Richard's banquet, counters the diner's culinary expectations: we don't expect meat pies to look like people, to stare back at us as we cut into them, but when they do eating them is bound to provoke a shiver of excitement, our acknowledgement that we are flirting with the forbidden.

This fascination with the unexpected, with flouting the rules that traditionally govern food and its consumption, is not unique to the 
Turk's Head. I mentioned above the medieval penchant for illusion, or counterfeit, food, a feature of both aristocratic and bourgeois dining that serves simultaneously to entertain guests and impress them with the status and resources of their host. The appeal of many late medieval entremets, like the appraylere (ground meat moulded and painted to resemble a clay pitcher) and yrchoun (a hedgehog of pork spiked with almond quills), lies precisely in their power to disturb the neat divide between what is and what isn't edible. ${ }^{32}$ Evidence, from recorded aristocratic banquets as well as sources like the Turk's Head, and its close counterpart Priest's Head (tête de cure), indicates that these illusions include feigned anthropophagy. To the extent that entremets function as an assertion of the host's lordship (the authority that goes hand in hand with social magnificence), they also serve to remind the guest of the risk that inheres in dining out; this is usually illusory but, in the case of royal or other politically motivated events, it doubtless has very real implications. ${ }^{33}$ One recipe demands that a roasted peacock be returned to its plumed skin (skilfully removed before cooking) and served 'as if it were alive'; a second provides instructions for a mercury concoction that causes a cooked fowl to jump animatedly in its dish; a third recommends hiding live birds inside a pie shell so that they fly out when the pie is cut open. ${ }^{34}$ These dishes and others like them force the diner to acknowledge that the host, even if apparently only in jest, has the power to conjure life itself and, by implication, death. When a pie shell contains not simply birds but a complete orchestra of musicians, as it did at Philip the Good's extravagant Feast of the Pheasant held at Lille in February I454, we are necessarily impressed not only with the enormity of the pie but the magnitude of the host's prerogative.

If we think about Richard's Saracen's Head as a conventional entremets, as the narrative, scrupulously attentive to the naturalistic detail of the feast, encourages us to do, then there is nothing absurd about it at all. ${ }^{35}$ Like other successful entremets, it articulates, with inescapable clarity, the nature and extent of the host's authority; it asserts his hegemony and in its blatant exhibitionism confirms his ability to enforce it. What distinguishes these Saracens' Heads from other recorded entremets is, of course, that they demand not illusory but actual anthropophagy. I have already argued, given the ambitions of the crusaders and those who share their fantasy of Christian dominion, that there is scant difference between the illusory and the actual. Key to my reading of the Turk's Head (in section I) is my conviction that the familiar binaries edible and inedible are not so much opposed categories of meaning as points on a continuum that can - and do - 


\section{38 Nicola McDonald}

move toward one another. Eating a meat pie that looks like a Turk's head is just a step away from eating a real Turk's head. Conventionally, we understand the difference between these two acts of ingestion in terms of another pair of binaries: metaphoric and literal. Eating a Turk's Head is permissible because it is simply metaphoric; eating a Turk, because literal, is on the other hand prohibited. But, as I discussed above, these binaries too prove to be inadequate. When metaphoric consumption (eating a Turk's Head) symbolises literal consumption (the fantasy of Muslim genocide) we cannot be content with the security - the impunity - of the metaphor. I want now to consider how this shift from the metaphoric to the literal, evident in Richard's presentation and consumption of real Saracens' heads, is consistent with the poetic (and not just alimentary) logic of the romance.

\section{III}

Ambroise, author of the Estoire de la guerre sainte and putative eyewitness to the events of the Third Crusade, provides the earliest extant reference to Richard's cognomen 'quor de lion', but it is certainly not original to him. Bernard Itier, a Benedictine monk at Limoges records in his memorandum on the king's death in II99 that Richard was known as 'Cor Leonis' and William the Breton, a chronicler in the retinue of Philip Augustus, likewise designates Richard 'corde leonino' (lionhearted). ${ }^{36}$ The popularity of the epithet, standard in references to Richard by the mid-thirteenth century, confirms his reputation, already well established in his lifetime, as a fierce and noble warrior. 'Lionheart', as the chroniclers (and we) understand it, is a metaphor: it works by means of an implied figurative comparison between Richard and the lion. Richard is not a lion; his heart is not a lion's heart; the metaphor, in fact, tells us nothing about lions at all. Rather, Richard, celebrated for his martial valour, exhibits certain qualities (might, courage, ferocity, nobility) that we (and the medieval bestiaries) conventionally attribute to the lion. What distinguishes metaphor according to the classical definition - is precisely its interruption or violation of the mimetic codes that govern literal expression.

In Richard, however, 'lionheart' is transformed into a narrative event. At the court of Almeyne Richard wins his famous cognomen by wrenching the heart out of a ferocious lion. The romance undoes the violation inherent in the metaphoric epithet and renders it mimetically coherent. ${ }^{37}$ Richard is 'cœur de lion' not on account of his 
figurative likeness to a lion but because he literally wins a lion's heart. The manuscripts (with the exception of Auchinleck which omits it entirely) record two slightly different versions of the episode. In the more 'historical' version (the version which omits his magical birth and consumption of the Saracen), Richard strangles the lion and then, cutting it open with a knife, removes the heart. In the inflated 'romance' text (the version of Richard that I am interested in) the knife is omitted; Richard thrusts his arm down the animal's throat, rips out its heart and (to the surprise of the King of Almeyne in whose salt cellar he dips the bloody meat) eats it. That Richard's identity is contingent on an act of ingestion accords with the narrative's alimentary logic. The figurative analogy implicit in the chroniclers' designation of Richard as 'lionheart' is rendered baldly literal; it is recast as a simple act of (alimentary) cause and effect: you are what you eat. Equally important, however, is what this episode - and its successive transformations - tells us about the poetic code that operates in Richard. 'Lionheart' as narrative event is effectively a spelling out - a clarification and explanation, achieved by actualising a metaphor - of Richard's cognomen. Here (and I would argue elsewhere in the romance) Richard rejects the metaphoric as a mode of both discourse and action and embraces instead the literal. As modern readers, we have learned to privilege the metaphor; literal signals to us something naive or crude and indeed critics of popular romance regularly dismiss the genre as just that. The kind of spelling-out that the lion heart episode effects is, in fact, remarkably consistent with what scholars identify as fundamental to the genre: a stripped-down narrative, comprised of a sequence of linearly coherent events, that moves with singular purpose toward a self-evident resolution. Popular romance is distinguished by the way in which it prioritises plot, what Peter Brooks calls the 'organizing line and intention of narrative'. ${ }^{8}$ The result is an enormously satisfying, event-filled story, but one that achieves satisfaction at the expense of what we, as academic readers, have been trained to value in a literary text: structural complexity, ambiguity, resistance to closure, and a sophisticated use of metaphor (among other things).

There is of course nothing necessarily second rate about literal, or mimetic, discourse. On the contrary, to the extent that it refuses the mediation inherent in metaphor - the distance that, for instance, separates the sweet-and-sour Turk's Head pie from Muslim genocide - it provides an uncompromising immediacy, a bluntness that demands that we confront head-on events or ideas that elsewhere remain camouflaged in indirection. The kind of spelling out that we find in 
Richard forces us to acknowledge the presence of a fully legitimated anthropophagy, real and imagined, in Western culture. I want to conclude this essay by suggesting that Richard's anthropophagy derives meaning from (and disturbs our understanding of not only the conventions of late medieval cuisine, but a blatantly literal eucharistic theology. Eating people - literally - is the prerogative of the virtuous Christian.

The textual history of Richard is complex (the product not only of translation but at least two revisions), but I am confident that the redactor who transforms Richard into a man-eater also rewrites the lion heart episode to include his consumption of the heart. Likewise, the same redactor substitutes Cassiodorien, a fairy princess, for Richard's historical mother Eleanor of Aquitaine and invents the episode in which she flees the mass through the roof of the church. That all of these incidents are the product of a single redactor is not coincidental. The Cassiodorien episode, added to the start of the romance, not only provides Richard with the kind of mythical parentage common to romance heroes, but effectively initiates the narrative that follows. A beginning, as Edward Said reminds us, is a 'formal appetite'; it signals narrative desire, a 'hunger' (as Said sees it) for a particular kind of story. ${ }^{39}$ Popular romance tends to have sharply demarcated beginnings and endings. The insistence with which it signals its parameters is key to understanding the logic of the story: romance does not so much demand a 'willing suspension of disbelief' as create its own system of belief. Romance logic, like its morality, is self-reflexive. This is not to say that romance cannot reflect broader cultural realities, but simply that within its parameters (from the 'hic incipit' through to 'Amen. Explicit' of each individual romance) the audience is invited to participate in to believe in - the narrative system that makes that romance cohere. The Cassiodorien episode, interesting precisely because it is a late addition to the romance, stands out for the way in which it is purposefully productive of the hunger that, as we have seen, drives Richard.

Like many progenitors of romance heroes, Cassiodorien has a touch of the diabolical; and, as we might expect, she passes this on to her son. Richard, much like Sir Gowther, is in effect a narrative of exorcism: an account of how Richard successfully purges himself of his devilish inheritance. Significantly, Richard's anthropophagy, far from being a sign of that inheritance, not only marks, but produces, his return to the Christian community. Cassiodorien's alterity is a function not of her obscure origins, her otherworldly beauty, or her exotic attire, but of her inability to sit through the mass. On her first visit to church she faints just before the consecration of the host, is carried 
away to her chamber and only returns, fifteen years later, when a powerful earl challenges Henry with his wife's impiety. On this second occasion, her reaction is more definitive: at the moment of consecration, she flies out through the roof and never returns. The narrative is careful to locate Cassiodorien's alienation from the mass in the 'sakeryng' (222), the precise moment at which the bread and wine of communion, elevated for the congregation to see, is transformed into the body and blood of Christ; as she says herself, 'I dar neuere see pe sacrement' (I94). Cassiodorien, like the witches, Jews and heretics (all familiar host abusers) of popular eucharistic miracles, is outed, so to speak, by the corpus verum, the wheaten disc that once consecrated (so late medieval theologians insist) is the actual flesh and blood of Christ in all of its materiality. Cassiodorien is unable to participate in the ritual of theophagy, the holy anthropophagy that binds Christian communicants into a harmonious community of believers; she is prohibited from seeing the eucharist - an act considered sufficiently analogous to literal consumption that even Alexander of Hales (who denies its sacramental nature) speaks of 'eating by sight' (manducatio per visum) - and so she is expelled from the community. ${ }^{40}$

Although Cassiodorien is never mentioned again, we understand that Richard, judged by more than one knight as 'a deuyl' (500) or 'pouke' (568), takes up arms in direct response to the taint of impiety that necessarily, after his mother is exposed as an unbeliever, adheres to him..$^{41}$ Crusading is well known in romance as a sure means to salvation and the Pope is explicitly cited as promising Richard eternal 'paradys' (I326) in exchange for his assault on the Saracen-controlled Holy Land. Richard flaunts the trappings of piety (his tournament disguises, for instance, all sport elaborate devices that align him against his mother's kin - heathens, unbelievers, and God's enemies) and he sets about crusading with a palpable urgency. His anthropophagy is positioned at the mid-point of the narrative and divides it into two distinct halves. A thirteen-line invocation to May (flowers, birdsong, and amorous couples (3759-7I)) immediately follows the Saracen Head banquet and, precisely because it is abrupt and contextually inappropriate, confirms the formal rupture that the anthropophagy effects. Structurally speaking, the first half of the romance finds its resolution in Richard's consumption of the Saracen. Richard does not yet gain the promised paradise (that awaits his combat with Saladin in the second half of the romance) but what he does achieve, in overt contrast to his mother, is an assured identity as a Christian. For the first time in the romance, Richard can assert, with impunity, ' $\mathrm{j}$ am kyng, Cristen, and 
trewe' (35I4) because his holy anthropophagy (Saracen flesh consumed in the service of God) performs the same function as conventional Catholic theophagy. Like the eucharist, it is authorised by Christ as a sign of 'hys grace and his vertu' (3067); it replicates the sacrament's power to restore the communicant to health (the medicinal quality of the Host is a commonplace of eucharistic verse), successfully rendering Richard 'hool and sounde' (3II8); it forges a corporate Christian identity ("per is no fflesch so norysschaunt / Vnto an Ynglyssche Cristen-man' (3548-9)) that is defined as much by purposeful exclusion as inclusion (the Saracens report to Saladin 'Non off vs eet morsel off bred, / Ne drank off wyn' (3635-6)); and, for one extraordinary instant, it demands that man eat man. ${ }^{42}$

The extent to which late medieval Christians both recognise and embrace the anthropophagy inherent in the sacrament of the eucharist is well attested. ${ }^{43}$ The doctrine of the Real Presence - the belief that Christ is literally present, in flesh and blood, in the consecrated host is made manifest in an iconography (verbal and visual) of food and eating that is at once homely and outrageous. Hungry communicants not only feed on 'Crist in a cake', the 'sopefast mete' that is commonly received 'in fourme of bred' or as 'rosted' flesh, they do so with enthusiastic 'smackyng', marvelling at its 'deliciows' flavour or distinctive 'swetness'; at times Christ is 'oure sugre', at others he is simply 'foode' ${ }^{44}$ Culinary metaphor transforms the crucifixion into an exercise in baking: the wheat is 'presschen', the 'curnel[s]' pounded into 'meole', 'knede[d]' and 'molded' into loaves, and finally, in an extraordinary rendition of the entombment, 'don in pe ouene'. ${ }^{45} \mathrm{Sin}$, on the other hand, renders the host 'raw flessch bledyng': a woman who denies the sanctity of something as mundane as bread, for instance, finds in its place a bleeding finger. ${ }^{46}$ Even more arresting, however, are those eucharistic exempla in which a priest, sometimes having slaughtered him first, eats a small boy. These narratives commonly depict the anthropophagy as a god-sent vision (designed either to reward the virtuous believer or to incite the unbeliever's conversion), but there is nothing ephemeral about the way they figure the communicant as a man-eater. ${ }^{47}$ At the moment of elevation, the priest raises up not a white disk but a bloodied infant - 'a ffeir child, I-woundet sore', 'a child blodie', as one fifteenth century English sermon describes it and proceeds, in the company of the other mass-goers, to eat his gory meal: '[he] ete pe child / pat he bi-twenen his hondes held / And al pat weore in pe churche permide / ... so heo dude.$^{48}$ More gruesome is Robert of Brunne's account of the doubtful religious: at the moment 
of consecration, a living child 'in feyr forme, of flesshe \& blode' is hacked to pieces on the altar; chunks of his bloodied flesh ("Morselles of pe chyld al newe sleyn / ... / Wyp al pe blode per on al fresshe') are offered to the communicant and, awe struck, he believes. ${ }^{49}$ What these so-called miracles demonstrate, as they flout the taboos against infanticide and anthropophagy, is the audacity of medieval eucharistic piety.

The requirement that Christ be literally present in flesh and blood - real to see, touch and taste - on the altar, in the priest's hands and in the communicant's mouth liberates us to imagine the unimaginable and, more significantly, forces us to record these fantasies in words and images. Acts conventionally deemed transgressive no longer elicit opprobrium; indeed they incite, and license, other fantastic acts. ${ }^{\text {so }}$ When Hugh of Lincoln, for instance, is rebuked by the abbot of Fécamp for gnawing like a dog on the arm bone of Mary Magdalene, he dismisses him with eucharistic logic: 'If, not long ago, we have touched the most sacred body of the Lord of the saints with our fingers, however unworthy, and having touched it with our teeth and lips absorbed it in our stomach, why should we not ... confidently handle in the same way the body parts of his saints. ${ }^{{ }^{51}}$ Eating people, that inveterate Christian taboo, is simultaneously one of its most potent fantasies. The ideology of Christian communion, the desire of individual and community to forge their identity around the shared ingestion of a man-god's flesh, is an enormously productive ideology of licensed anthropophagy, literal and metaphoric. Richard's consumption of the Saracen, constructed as both an alimentary necessity and an act of sacral devotion, provides the romance audience with a convenient focus for its own fantasies of religious supremacy, political dominion, nationalism and a good meal. Richard, like so many popular romances, is resolutely logical; driven by hunger (for the body of Christ, foreign lands, and material sustenance) it finds satisfaction in the literal ingestion of the Saracen, the alien other whose annihilation Western culture demands. Richard's logic is disturbing (it's meant to be) but it is certainly not, any more than Ariel Sharon's 'Arabs for breakfast', absurd.

\section{Notes}

Thanks are due to Ann Rycraft and Hélène Tronc for innumerable conversations about food, medieval and modern, and anthropophagy and to Victoria Stavely for her culinary experiments.

I Diuersa Cibaria in Curye on Inglysch, eds C. Heiatt and S. Butler, EETS s.s. 8 (London, I985), p. 48 . The recipe is extant in three manuscripts, one 


\section{I44 Nicola McDonald}

Anglo-Norman (British Library, MS Royal I2 C. xii, fol. I2v (c. I320-40)) and two English (British Library, MS Additional 469I9, fol. 20v (before I333); British Library, MS Cotton Julius D. viii, fol. IO5v (c. I450)).

2 Michael Flanders, 'The reluctant cannibal', The Songs of Michael Flanders and Donald Swann (London, I977), pp. 64-6.

3 The word 'cannibal' derives from Caniba, a variant of Carib, the term used by the both the islanders and Spanish colonists to designate the natives of the Caribbean islands. Columbus promoted the belief that the Canibales were savage man-eaters; their reputed dietary transgressions were quickly exploited by the colonists as a justification for the decimation of native culture and its practitioners. Peter Hulme argues that "“cannibalism" is a term with no application outside the discourse of European colonialism', Colonial Encounters (London, I986), p. 84. See also F. Lestringant, Cannibals: The Discovery and Representation of the Cannibal from Columbus to Jules Verne, trans. R. Morris (Berkeley and Los Angeles, I997), pp. I 5-I7.

4 The Psalter (British Library, MS Additional 2868 I, c. I250), Ebstorf (thirteenth century), and Hereford (c. I 300 ) mappaemundi all relegate anthropophagi to the far south of the world, on the edges of Africa and at Christ's extreme left; John Mandeville locates his anthropophagi in the east, in the vicinity of Ynde, in places like Sumatra, the Andaman Islands and Tibet. The Mongols (or Tartars) were routinely stigmatised as maneaters and when they invaded Eastern Europe in the thirteenth century, Western fear conjured ever more graphic images of their reputed loathsome diet; Matthew Paris, for instance, depicts Tartar practice in a gruesome illumination in his Chronica Universale (discussed below in section II). Accusations of domestic, European anthropophagy were directed against Jews (and closely linked to the accusations of ritual murder discussed by Miri Rubin in Corpus Christi: The Eucharist in Late Medieval Culture (Cambridge, I99I) and Gentile Tales: The Narrative Assault on Late Medieval Jews (Yale, I999)) and witches (see Richard Kieckhefer, European Witch Trials: Their Foundations in Popular and Learned Culture, 1300-1500 (London, I976), passim and Reay Tannahill, Flesh and Blood: A History of the Cannibal Complex (London, 1975), pp. 92-107), as well as the Tafurs, a troop of hungry desperadoes who, at Antioch and Ma'arat-an-Nu'man, gorged on the rotting corpses of the Muslim enemy. See L. A. M. Sumberg, "The "Tafurs" and the First Crusade', Medieval Studies, 2 I (I959), 224-46 and J. Tattersall 'Anthropophagi and eaters of raw flesh in French literature of the Crusade period: myth, tradition and reality', Medium Aevum, 57 (I988), 240-53.

5 The fourteenth-century Forme of Curye (compiled by Richard II's chief cook) includes a recipe for cokantrice (Curye on Inglysch, eds Hieatt and Butler, p. I39); similar recipes are found in the fifteenth-century: Two Fifteenth-Century Cookery-Books, ed. T. Austin, EETS o.s. 9I (London, I 888), pp. 40, I I 5. Instructions detailing 'how somme mete schalle seme raw' are found among other 'slyztes of cure' in the Liber Cure Cocorum, ed. R. Morris (Berlin, I862), p. 5. 
6 See Terence Scully, 'The medieval French entremets', Petits Propos Culinaire, I7 (I984), 44-56; Danielle Queruel, 'Des Entremets aux intermedes dans les banquets Bourguignons', in Banquets et manières de table au Moyen Age (Aix-en-Provence, I996), pp. I43-57; and Bridget Ann Henisch, Fast and Feast: Food in Medieval Society (University Park, PA, I976), pp. 206-36 for an introduction to the origin and history of the entremets.

7 The mock battle is illustrated in the Grandes Chroniques de France, Paris, Bibliothèque nationale, MS. fr. 28 I 3, fol. 473v (c. I 379). See L. H. Loomis, 'Secular dramatics in the royal palace, Paris, I 378, I389, and Chaucer's "tregetoures"”, Speculum, 33 (I958), 242-55; also Henisch, Fast and Feast, p. 234.

8 Claude Lévi-Strauss first coined the terms 'good to eat' (bon à manger) and 'good to think' (bon à penser) in his analysis of the totemic value of animals (Totemism, trans. R. Needham (London, I964), p. 89); the terms were quickly extended to the study of food by anthropologists sympathetic to Lévi-Strauss's structuralist ideology.

$9 M E D$, eten (v.) 4c; devouren (v.) 3b; swolwen (v.) 2d; glotoun (n.) Ib; feste (v.) Ia.

Io Richard Coeur de Lion. Der Mittelenglische Versroman über Richard Löwenherz, ed. Karl Brunner (Vienna, I9I3), lines 5489-91. All quotations from Richard will be from this edition and will be cited by line number in the text of the essay.

I I For a summary of Catholic doctrine on the eucharist (including transubstantiation and the 'Real Presence') see The New Catholic Encyclopedia, I5 vols (Washington, DC, I967): 'Eucharist', vol. 5, pp. 594-6I 5; 'Transubstantiation', vol. I4, pp. 259-6r. Miri Rubin outlines key medieval debates on the nature and substance of the eucharist in Corpus Christi, pp. I4-35.

I2 Sally Kevill-Davies, Antique Pocket Guides: Jelly Moulds (Guildford, I983) reproduces a selection of eighteenth-century moulds as well as an illustrated page of earthenware blancmange moulds from Copeland's I902 catalogue (see especially pp. I I-I2, 27). The I 88 I catalogue for Simmons Hardware Company in St Louis, Missouri advertises large and small metal Turk's head pans; the relevant page is reproduced in R. Barlow (ed.), Victorian Houseware, Hardware and Kitchenware: A Pictorial Archive with over 2000 Illustrations (Mineola, NY, I992), p. I09. Current popularity of the distinctive mould is suggested by baking guru Rose Levy Beranbaum; 'my favorite mold [for fruitcake] is a ... Turk's head': The Cake Bible (New York, I988), p. 68.

I3 See Nabil I Matar, 'Renaissance England and the turban', in D. Blanks (ed.), Images of the Other: Europe and the Muslim World Before 1700 (Cairo, I997), pp. 39-54 for an informative account of the politics of turbans and Turks' heads in Renaissance England; Matar's argument has clear implications for medieval representations of Islam and the Arab world.

I4 Quoted during the $200 \mathrm{I}$ Israeli election campaign in Independent on Sunday, 28 January 200I; Jean Marie Le Pen, leader of France's ultra rightwing Front National, makes a similar claim: 'Je mange du musulman 
tout cru à mon petit déjeuner comme ne l'interdit pas le Prophète'; cited in 'Les bons mots oubliés du chef, Le Canard enchaîné, 30 April 2002.

I5 George Ellis, Specimens of Early English Metrical Romances, 2 vols (London, I 805), vol. 2, p. I74; Sir Walter Scott, 'Introduction' (dated I832) to The Talisman, ed. W. M. Parker (London, I99I), p. 3; John Finlayson, 'Richard, Cor de Lyon: romance, history or something in between?', Studies in Philology, 87 (1990), I56-80 (pp. I6I, I65, I6I); W. R. J. Barron, English Medieval Romance (London, I987), p. I80.

I6 Cronicon Richardi Divisensis de Tempore Regis Richardi Primi. The Chronicle of Richard of Devizes of the Time of King Richard the First, ed. and trans. J. T. Appleby (London, I963), p. 77.

I7 Geraldine Heng, 'The romance of England: Richard Coer de Lyon, Saracens, Jews, and the politics of race and nation', in J. J. Cohen (ed.), The Postcolonial Middle Ages (New York, 2000), pp. I35-7I (p. I37 and passim).

I 8 Richard is extant in seven imperfect manuscripts conventionally divided into a longer, more fabulous, A version - Cambridge, Gonville and Caius College, MS I75/96 (c. I400); London, British Library, MS Additional 3 IO42 (c. I 440) - and a shorter, more historical, B version - Edinburgh, National Library of Scotland, MS Advocates I9.2.I, the so-called Auchinleck manuscript (c. I330); London, College of Arms, MS Arundel 58 (c. I400-50); London, British Library, MS Egerton 2862 (c. I390); London, British Library, MS Harley 4690 (fifteenth century); Oxford, Bodleian Library, MS Douce 228 (late fifteenth century). Richard was printed by Wynken de Worde in I 509 and I 528; the printed text is very close to the so-called A version manuscripts. Karl Brunner's I9I3 edition of Richard (which remains the most recent and only readily available edition) uses Cambridge, Gonville and Caius, MS I75/96 as its base text, supplemented by Wynkyn de Worde's prints for the following lines missing from the Cambridge manuscript: 227-449, 679-796, I736-2468, 6864992. A new edition is long overdue, but since all manuscripts are imperfect no edition, with a readable complete text, can ever be wholly satisfactory.

I9 Gaston Paris, 'Le Roman de Richard Cœur de Lion', Romania, 26 (I897), 353-93 (pp. 36I-2); Brunner, Der Mittelenglische Versroman über Richard Löwenherz, Introduction I.4: pp. I7-23.

20 John Gillingham, Richard I (New Haven, I999) provides the most up to date and thorough account of Richard's life and reign.

2 I The longer A version of Richard is conventionally distinguished from the shorter B version by its inclusion of fabulous romance-like material which disrupts B's historicity; Finlayson, 'Richard, Cor de Lyon: romance, history or something in between', attempts to identify, episode by episode, the historically verifiable core that underlies the romance. Yet, as even Finlayson notes (p. I6I), all extant manuscripts, other than Auchinleck, contain some non-historical 'interpolated' material.

22 The defective nature of Richard's manuscripts makes it difficult to assert with confidence exactly how much fabulous material each extant text 
originally contained. I have, however, noted that those manuscripts (Arundel 58, Harley 4690 and Douce 228) that identify Eleanor of Aquitaine as Richard's mother and Berengaria of Navarre as his wife (2040b: I-I3), thereby maintaining a modicum of historical accuracy, omit not only the fabulous Cassiodorien (as we might expect), but also Richard's anthropophagy and his consumption of the lion's heart. There is no reference to Eleanor or Berengaria in Auchinleck, but it is deficient at the relevant point in the text so we can draw no firm conclusions; since it omits Cassiodorien there is no reason why it should not include Eleanor. Gonville and Caius 175 and Additional $3 \mathrm{IO}_{2}$ start with Cassiodorien as Richard's mother, omit Eleanor and Berengaria, and include both his anthropophagy and his eating of the lion's heart; Egerton 2862 is illegible at the start (so it is not possible to confirm its inclusion of the Cassiodorien episode) but both Richard's anthropophagy and his eating of the heart are included. See section III below for a discussion of the significance of these additions (and omissions).

23 Henry Fielding, Tom Jones, eds F. Bowers and M. C. Battestin, 2 vols (Oxford, I974), vol. I, p. 509.

24 See W. C. Jordan, The Great Famine: Northern Europe in the Early Fourteenth Century (Princeton, I996) for a comprehensive account of late medieval European famine.

25 For fruit and vegetables as peasant food see C. Dyer 'Did the peasants really starve in medieval England?', in M. Carlin and J. T. Rosenthal (eds), Food and Eating in Medieval Europe (London, I998), pp. 53-7I (p. 63). For horse flesh as a taboo meat see F. J. Simoons, Eat not this Flesh: Food Avoidances from Prehistory to the Present, 2nd edition (Madison, I994), pp.79-86; for an account of both horse flesh and inferior foods as a sign of famine see J. Marvin, 'Cannibalism as an aspect of famine in two English chronicles' in Carlin and Rosenthal (eds), Food and Eating in Medieval Europe, pp. 73-85.

26 Susan E. Farrier underlines the general absence of any practical reference to food in Middle English romance in her essay 'Hungry heroes in medieval literature', in Melitta Weiss Adamson (ed.), Food in the Middle Ages: A Book of Essays (New York, I995), pp. I45-59 (pp. I45-6).

27 The enraged Saladin, learning that his compatriots have been eaten, condemns Richard as a 'deuyl' (3664); Philip of France's censure is implicit in his decision, when hungry and ailing, to eschew the English king's restorative diet of cooked Saracen, choosing instead to return to Europe (5467-80, 5913-30).

28 Dishes like Bruette Sareson (a type of beef stew) and Saunc Sarazine, alternately called Sawse Sarzyne, (an almond flavoured sauce commonly coloured red) use ingredients, cooking techniques and colours imported from and associated with Eastern cuisine; all three can be found in Curye on Inglysch, eds Hieatt and Butler, pp. 72, 86, I I7. C. Anne Wilson provides a survey of the Arab flavour of medieval cuisine in a pair of articles: 
'The Saracen connection: Arab cuisine and the medieval West: part I' and 'The Saracen connection: Arab cuisine and the medieval West: part 2', Petits Propos Culinaire, 7 (I98I), I3-22 and 8 (I98I), I9-28.

29 Geoffrey of Monmouth, The Historia Regum Britannie of Geoffrey of Monmouth I: Bern, Burgerbibliothek, MS. 568, ed. Neil Wright (Cambridge, I984), p. I65; Alliterative Morte Arthure in King Arthur's Death, ed. L. D. Benson (Exeter, I986), lines I049-52.

30 Suzanne Lewis, The Art of Matthew Paris in the Chronica Majora (Aldershot, I987), fig. I 80 .

3 I See for instance, The Seege or Batayle of Troye, ed. M. E. Barnicle, EETS o.s. I72 (London, I927), lines 2052-6; Havelok, ed. G. V. Smithers (Oxford, I987), lines I725-30; Of Arthour and of Merlin, ed. O. D. MacraeGibson, EETS o.s. 268 (London, I973), lines 31 I7-23. See also Two Fifteenth-Century Cookery-Books, ed. Austin, pp. 57-64 and pp. 67-9 for a selection of historic menus; these unelaborated documents simply list the meats and dishes served.

32 A recipe for yrchouns is included in the Forme of Curye (Curye on Inglysch, eds Hieatt and Butler, p. I39); recipes for both yrchouns and appraylere are edited by Austin (Two Fifteenth-Century Cookery-Books, pp. 38, 39).

33 Felicity Heal reminds us that for the guest, or outsider, the unfamiliar household was a 'potentially hostile environment'; the guest's 'very security' is dependent on the 'belief that [the] host will obey the laws of hospitality: Hospitality in Early Modern England (Oxford 1990), p. I92. In an informative study of table manners that insists on the violence inherent in eating, Margaret Visser proposes that '[b]ehind every rule of table etiquette lurks the determination of each person present to be a diner, not a dish', The Rituals of Dinner: The Origins, Evolution, Eccentricities and Meaning of Table Manners (Harmondsworth, I992), p. 4.

34 A recipe for Pecock rosted is edited by Austin, Two Fifteenth Century CookeryBooks, p. 79; Albertus Magnus provides instructions for the preparation of a leaping chicken: 'If thou wilt that a Chicken or other thing leap in the dish', The Book of Secrets of Albertus Magnus, eds M. R. Best and F. H. Brightman (Oxford, I973), p. 98; and the recipe for 'De pastillo auium uiuarum' is found in the Liber de Coquina: 'Deux traités inédits d'art culinaire médiéval', ed. Marianne Mulon, Bulletin philologique et historique (jusqu'à 1610) du comité des travaux historiques et scientifiques (I968), vol. I, pp. $368-435$ (p. 405).

35 Key details suggest that for Richard (and the narrator) the Saracen's Head is purposefully designed to function as an entremets: it is piped in with a characteristic flourish of music; it is served one dish between two diners in conventional aristocratic fashion; and a parchment name-tag, effectively explaining its political as well as culinary significance, is affixed to each head. For a useful comparison with historical entremets see Scully, 'The medieval French entremets', Queruel, 'Des Entremets' and Henisch, Fast and Feast. 
36 Ambroise, L'Estoire de la Guerre Sainte, ed. G. Paris (Paris, I897), line 23 Iо; Bernard Itier, 'Obitus Richardi Regis', La Vérité sur la mort de Richard Cour-de-Lion Roi d'Angleterre, ed. L'Abbé Arbellot (Paris, I878), p. 6I; William the Breton, Philippidos, in Oeuvres de Rigord et de Guillaume le Breton, ed. H. F. Delaborde, 2 vols (Paris I885), vol. 2, p. 396.

37 Richard provides the first extant account of 'lion heart' as a narrative event. Loomis has suggested, on the evidence of the Chertsey tiles, that the story, however, predates Richard. For the purpose of my argument, it does not matter if Richard's poet invented the story or not, but simply that he embraced it in all of its literalness. See R. S. Loomis, 'Richard Cour de Lion and the Pas Saladin in medieval art', PMLA, 30 (I9I5), 5Io-20.

38 Peter Brooks, Reading for the Plot: Design and Intention in Narrative (Cambridge, MA and London, I984), p. 37.

39 Edward Said, Beginnings: Intention and Method (New York, I975), p. 76.

40 Alexander of Hales's distinction manducatio per gustum and manducatio per visum is cited by Édouard Dumoutet in what is still the most complete study of the doctrine and practice of 'sacramental viewing', Le Désire de voir l'hostie et les origins de la devotion au saint-sacrement (Paris, I926), p. 20. Rubin, Corpus Christi, pp. 49-63; Eamon Duffy, The Stripping of the Altars: Traditional Religion in England 1400-1580 (New Haven, I992), pp. 95-102 and Leah Sinanoglou, 'The Christ Child as sacrifice: a medieval tradition and the Corpus Christi plays', Speculum, 48 (I973), 49I-509 all provide accounts of popular, sometimes frenzied, devotion to 'seeing God'. As the laity was increasingly distanced from the touch and taste of the host, sight (signalled by the ringing of the sacring-bell and the elevation of the host) became paramount and the elevation provided the climax of the mass; see T. W. Drury, Elevation in the Eucharist: Its History and Rationale (Cambridge, I907), p. I25 and passim.

4I Richard's brother John is likewise tainted with diabolical blood - 'Jhon,/ pat was the fendes fflesch and bon' $(6335-6)$ - but for him, of course, there is no redemption.

42 See John Bossy for his classic account of the mass as productive of corporate identity and social integration, 'The Mass as a social institution, I200-I700', Past and Present, Ioo (I983), 29-6I; also relevant is Miri Rubin, 'The eucharist and the construction of medieval identities', in David Aers (ed.), Culture and History 1350-1600 (Detroit, I992), pp. 4363; the mass is, of course, equally productive of social division, but in Richard the analogy of the eucharistic feast is employed to underline the king's participation in a Christian community, not his exclusion from it.

43 See Rubin, Corpus Christi, pp. 359-60 and passim. Sister Loretta McGarry, The Holy Eucharist in Middle English Homiletic and Devotional Verse (Washington, I936) and Michele Theresa Priscandaro, Middle English Eucharistic Verse: Its Imagery, Symbolism and, Typology (New York, I975) offer comprehensive surveys of vernacular English eucharistic verse; both include a selection of explicitly anthropophagic material. 
44 These citations reflect only a tiny percentage of references to Christ as food; most are commonplace, repeated time and again in devotional literature, and the references below are by no means unique. 'Crist in a cake': 'Festivals of the church', Legends of the Holy Rood, ed. R. Morris, EETS o.s. 46 (London, I87I), p. 2 I I, line 40; 'sopefast mete': Oxford, Merton College, MS 248, fol. I67, 'Caro mea vere cibum' (C. F. Brown, A Register of Middle English and Didactic Verse, 2 vols (Oxford, I916-20), vol. I, p. I48, vol. 2, p. 207); 'in fourme of bred': 'Welcome, Lord, in fourme of bred', Minor Poems of the Vernon MS: Part I, ed. C. Horstmann, EETS o.s. 98 (London, I 892), p. 24, line I; 'rosted': Robert Mannyng, Meditations on the Supper of our Lord, and the Hours of the Passion, ed. J. Meadows Cowper, EETS o.s. 60 (London, I875), line 82; 'smakyng': 'Ronde in schapyng', Verses in Sermons: Fasciculus Morum ad its Middle English Poems, ed. S. Wenzel (Cambridge, MA, I978), p. I82, line 4; 'deliciows': Hoccleve, 'The song of graces of alle seintes upon Paske day', Hoccleve's Works III: The Regement of Princes and Fourteen of Hocleve's Minor Poems, ed. F. J. Furnivall, EETS e.s. 72 (London, I 897) p. 1, line I7; 'swetness': John Lydgate, 'The fifteen ooes of Christ', The Minor Poems of John Lydgate, ed. H. N. MacCracken, EETS e.s. I07 (London, I9I I) pp. 238-50, line 209; 'oure sugre': 'The fifteen ooes of Christ', line 2 I I; 'foode': 'The Magi', The York Plays, ed. R. Beadle (London, I982), line 32 I.

45 'Whon grein of whete is cast to grounde', in 'Proprium Sanctorum: Zusatz-Homilien des Ms. Vernon fol. CCXV ff. zur nördlichen Sammlung der Dominicalia evangelia', ed. C. Horstmann, Archiv für das Studium der Neueren Sprachen und Litteraturen, 8 I (1888), 83-5: lines 8I, 82, I I8, I I 5 , I20, I 26.

46 John Mirk, Mirk's Festial: A Collection of Homilies, ed. T. Erbe, EETS e.s. 96 (London, I905), p. I73, line 23.

47 See Sinanoglou, 'The Christ Child as sacrifice: a medieval tradition and the Corpus Christi plays'. Miri Rubin argues that the importance of the child-on-the-altar topos, as well as its frequency of representation, rose markedly from the thirteenth century and she aligns its popularity with 'the same trends which portrayed increasingly gory images of the crucified Christ'; Rubin, Corpus Christi, p. I39.

48 'De festo corporis Christi', The Minor Poems of the Vernon Manuscript: Part I, ed. Horstmann, pp. I68-97, lines I43, I77, I 53-6.

49 Robert Mannyng, Handlyng Synne, ed. Idelle Sullens (Binghamton, I983), lines 10055, 10066-8.

50 Miri Rubin likewise argues that the eucharistic miracles produce 'sites for fantasy', Corpus Christi, p. I39.

5 I 'Si ... ipsius Sancti sanctorum paulo ante corpus sanctissimum digitis licet indignis contrectauimus, dentibus quoque uel labiis attrectatum ad interiora nostra transmisimus, quare non etiam sanctorum eius menbra ... fiducialiter attrectamus ...?' (Magna Vita Sancti Hugonis, ed. D. L. Douie and H. Farmer, 2 vols, (London, I962), vol. 2, p. I70. 